Brief Communication

\title{
APECED in Turkey: A case report and insights on genetic and phenotypic variability
}

\author{
Alessandra Fierabracci $^{\mathrm{a}, *}$, Marsha Pellegrino $^{\mathrm{a}}$, Federica Frasca $^{\mathrm{a}}$, Sara Sebnem Kilic ${ }^{\mathrm{b}}$, \\ Corrado Betterle ${ }^{c}$ \\ a Infectivology and Clinical Trials Research Department, Children's Hospital Bambino Gesù, Viale S. Paolo 15, 00146 Rome, Italy \\ ${ }^{\mathrm{b}}$ Pediatric Immunology -Rheumatology, Uludag University, Medical Faculty Department of Pediatrics, Gorukle-Bursa 16059, Turkey \\ ${ }^{\mathrm{c}}$ Endocrine Unit, Department of Medicine (DIMED), University of Padua, Via Ospedale Civile 105, 35128 Padua, Italy
}

\section{A R T I C L E IN F O}

Keywords:

APECED-AIRE gene-genotype-phenotype

variability-Turkish population

\begin{abstract}
A B S T R A C T
APECED is a rare monogenic recessive disorder caused by mutations in the AIRE gene. In this manuscript, we report a male Turkish patient with APECED syndrome who presented with chronic mucocutaneous candidiasis associated with other autoimmune manifestations developed over the years. The presence of the homozygous R257X mutation of the AIRE gene confirmed the diagnosis of APECED syndrome. We further performed literature review in 23 published Turkish APECED patients and noted that Finnish major mutation R257X is common in Turks. In particular, we assessed retrospectively how often the Ferre/Lionakis criteria would have resulted in earlier diagnosis in Finns, Sardinians and Turks in respect to the classic criteria. Since an earlier diagnosis could have been possible in $18.8 \%$ of Turkish, in $23.8 \%$ of Sardinian and $38.55 \%$ of Finnish patients we reviewed from literature, Ferre/Lionakis criteria could indeed allow in future earlier initiation of immunomodulatory treatments, if found effective in future studies.
\end{abstract}

\section{Introduction}

Genetically determined autoimmune/immunodysregulatory disorders, more common in populations with a high rate of consanguineous marriages [1,2], include the Autoimmune Polyendocrinopathy-Candidiasis-Ectodermal Dystrophy/Dysplasia (APECED) or autoimmune polyendocrine syndrome type 1 . This represents a rare monogenic recessive disease caused by mutations in the autoimmune regulator (AIRE) gene encoding for a thymus-enriched transcription factor responsible for central immune tolerance [3]. The variability of APECED symptoms can be partly explained by the fact that AIRE is expressed not only in the thymus, but also in peripheral tissues, in lymphocytes, and associated with dendritic cells differentiation and their interaction with $\mathrm{T}$ cells [3]. A defect of CD4 + CD25 + regulatory $\mathrm{T}$ cells, key mediators of peripheral tolerance, is involved in APECED pathogenesis due to failure of their self-antigen-driven thymic development, maturation, peripheral activation and expansion [4,5]. Patients' sera harbor autoantibodies (Abs) to a restricted profile of tissue- specific antigens, in contrast to what could be theoretically expected from the extent of the AIRE-deficiency associated defect of thymic presentation [6]. Classic diagnostic criteria for APECED was the presence of two of the following disorders: chronic mucocutaneous candidiasis (CMC), hypoparathyroidism (HP) and Addison's disease (AD). Anti-interferon $\omega$ (IFN- $\omega)$ Abs are circulating at high titers. However, in 2009 diagnostic criteria were revised based on genetic and immunological data independently of the clinical manifestations [7]. Furthermore, 78\% of the APECED patients have non-endocrine manifestations before the first endocrinopathy [8].

In Finnish, Sardinian and Iranian Jew populations APECED develops at the highest described prevalences between 1:9000-1:25,000 [9] with homozygous AIRE mutations c.769C > T, c.415C > T and c.254A > $\mathrm{G}$ having a founder effect respectively [8-11]. The syndrome is detected at lower incidences and with greater genetic variability $[7,9,12-23]$ in many European countries. American APECED patients showed a diverse clinical picture, with dramatic enrichment of organspecific non-endocrine manifestations starting early in life, compared to

\footnotetext{
Abbreviations: Abs, autoantibodies; AD, Addison's disease; AADC, aromatic L-amino-acid decarboxylase; AIRE, autoimmune regulator gene; ANA, antinuclear Abs; APECED, auto-

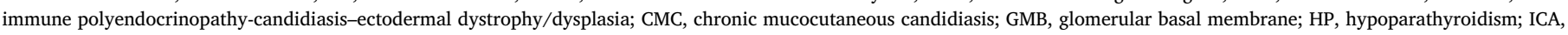

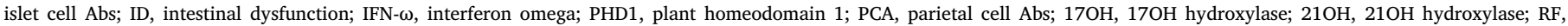
rheumatoid factor; rev, reviewed; RO52A, $52 \mathrm{kDa}$ Ro/SS-A molecule; ssc, side chain cleavage enzyme; TG, thyroglobulin; TPO, thyroperoxidase; TPH, tryptophan hydroxylase

* Corresponding author at: Infectivology and Clinical Trials Research Department, Children's Hospital Bambino Gesù, Viale S. Paolo 15, 00146 Rome, Italy.

E-mail addresses: alessandra.fierabracci@opbg.net (A. Fierabracci), marsha.pellegrino@opbg.net (M. Pellegrino), frasca.federica@virgilio.it (F. Frasca), sarasebnemklc@gmail.com (S.S. Kilic), corrado.betterle@unipd.it (C. Betterle).
} 
Table 1

Clinical presentation, other laboratory results of the APECED patient (altered parameters are in bold).*

\begin{tabular}{|c|c|c|c|}
\hline Age & Clinical manifestation/therapy & Autoantibodies (Abs) profile & Laboratory results \\
\hline from early life & Oral moniliasis and onychomycosis & & \\
\hline $\begin{array}{l}\text { 8-yo (admitted at Pediatric Immunology } \\
\text { Department, Uludag University }\end{array}$ & Chronic mucocutaneous candidiasis & & $\begin{array}{l}\text { Candida albicans growth from swab and } \\
\text { tissue cultures }\end{array}$ \\
\hline \multirow[t]{2}{*}{ 9-yo } & Watery diarrhea & & \\
\hline & $\begin{array}{l}\text { Abdominal distension (autoimmune } \\
\text { enteropathy) }\end{array}$ & & \\
\hline 9.6-yo & $\begin{array}{l}\text { Sjögren-like syndrome with dry eyes and } \\
\text { mouth }\end{array}$ & & \\
\hline \multirow[t]{10}{*}{ 10-yo } & Vitiligo & Positive Abs: & Anemia, otherwise \\
\hline & Alopecia & R052 & normal $\mathrm{CBC}$, ferritin and fibrinogen levels \\
\hline & Arthralgia on knee joints (the last treated with & $\mathrm{RF}(11.40 \mathrm{IU} / \mathrm{ml})$ & \\
\hline & non-steroid anti-inflammatory drugs) & TPH (164.3 U/ml) AADC (95.3 IU) & Elevated: \\
\hline & Autoimmune hemolytic anemia & IFN- $\omega$ (25 IU) direct Coombs test & $\begin{array}{l}\text { ESR, transaminases, } \\
\text { Serum Amyloid A, CRP } \\
\text { Borderline low serum creatinine, uric } \\
\text { acid, albumin and glucose }\end{array}$ \\
\hline & & Negative Abs: & \\
\hline & & ANA & \\
\hline & & $21 \mathrm{OHAbs}, 17 \alpha \mathrm{OH}, \mathrm{P} 450 \mathrm{scc}, \mathrm{TGA}$ & Low IgA (other Ig classes normal) \\
\hline & & TPO, ICA, PCA, GBM Abs & \\
\hline & & & $\begin{array}{l}\text { Homozygosity for AIRE c.769C }>\mathrm{T} \\
\text { (p.Arg257Ter) }\end{array}$ \\
\hline
\end{tabular}

ANA, anti-nuclear Abs; RO52, $52 \mathrm{kDa}$ Ro/SS-A molecule; RF, rheumatoid factor; TPH, tryptophan hydroxylase; AADC, anti-aromatic L-amino-acid decarboxylase; IFN- $\omega$, anti-interferon omega; 21OHA, 21OH hydroxylase; $17 \alpha \mathrm{OH}, 17$ alpha OH hydroxylase; P450scc: P450 side-chain cleavage enzyme; TG, thyroglobulin; TPO, thyroperoxidase; ICA, islet cell Abs; PCA, parietal cell Abs; GBM, glomerular basal membrane; CBC, complete blood count; ESR, erythrocyte sedimentation rate; CRP, C-reactive protein; Yo, years old.

* All 14 exons and intronic regions of the AIRE gene were sequenced according to already described protocols (Genetic Analyzer 3500 Applied Biosystems HITACHI system, ThermoFisher Scientific, Rodano (MI), Italy).

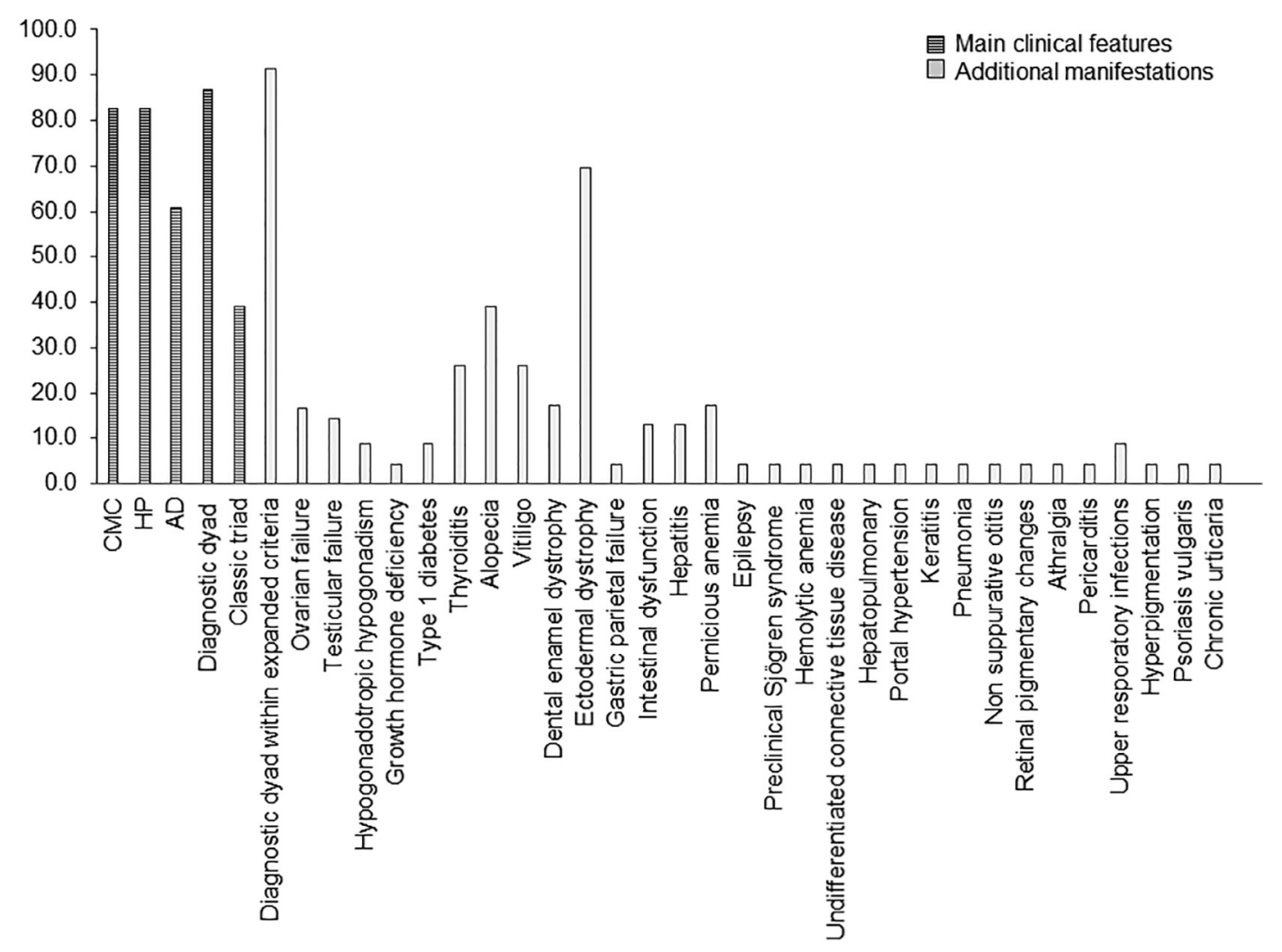

Fig. 1. Prevalence (\%) of clinical manifestations in the Turkish cohort. 


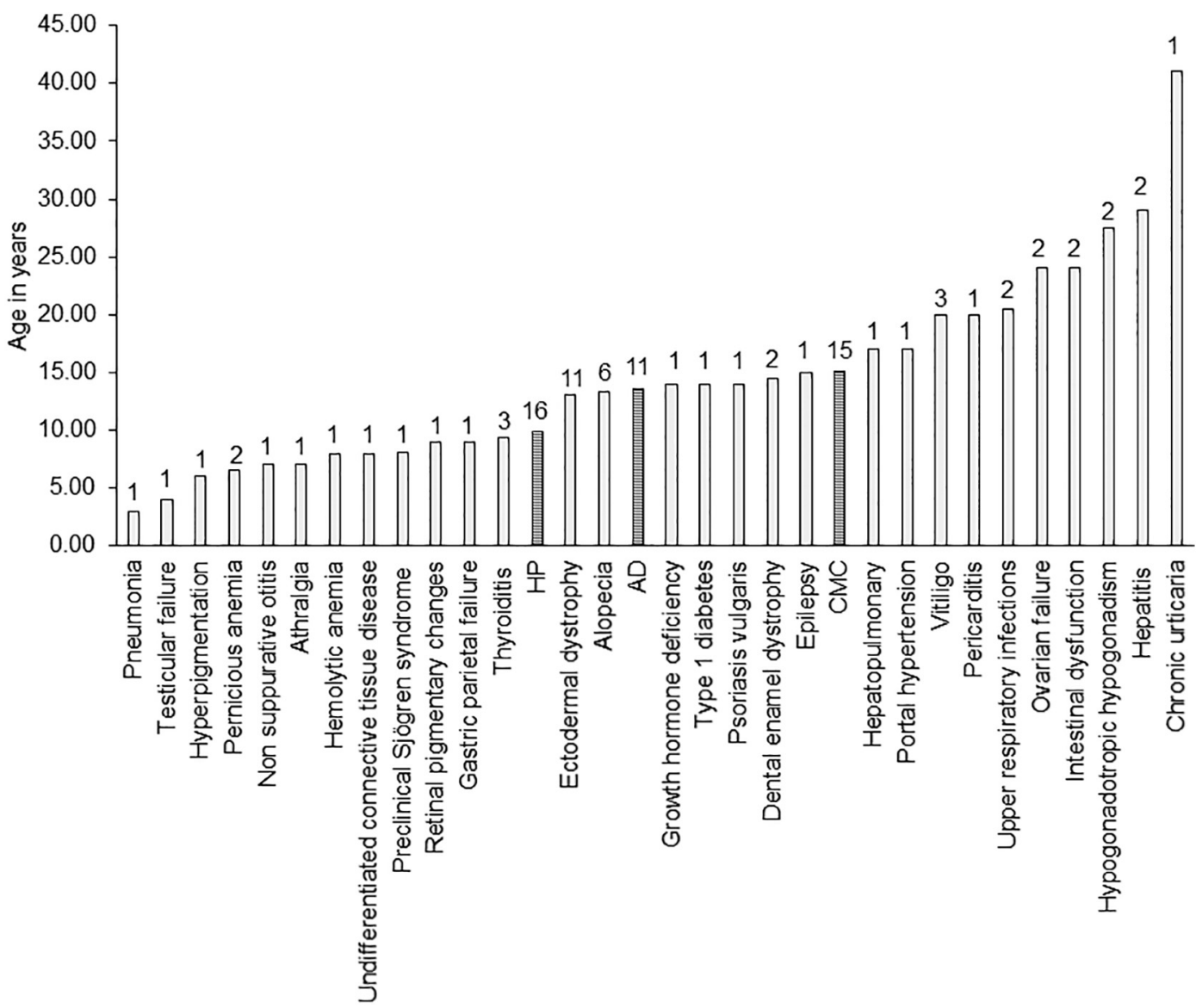

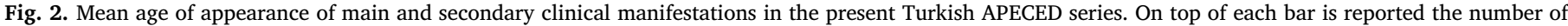
patients (among those whose age is known) corresponding to the underlying manifestation.

European cohorts [9]. In this regard, even in highest European prevalence cohort, the Finns, APECED patients show an increasing and higher recurrence of non-endocrine inflammatory manifestations, in particular autoimmune gastrointestinal dysfunction [24]. Interestingly, autosomal dominant AIRE mutations in the first plant homeodomain (PHD1) zinc finger are associated with organ-specific autoimmune conditions [25].

Epidemiological investigations thus raise questions about the validity and usability of the classic diagnostic criteria. In rare diseases, an early diagnosis generally improves prognosis and quality of life. Unlike in other autoimmune primary immunodeficiencies, APECED patients generally only receive endocrine replacement therapy [26] and no immunomodulation [27].

In this study, we report a new APECED male patient within the Turkish population and retrospectively evaluate Turkish APECED patients in comparison to data obtained in three particular cohorts derived from north (Finnish) [28] and south of Europe (Sardinian) [10], and from both North and South America [9]. Further objective was to verify whether the novel Ferre/Lionakis diagnostic criteria [9], which take into consideration the appearance of non-endocrine manifestations, could improve the diagnostic efficacy in different APECED series. Specifically, clinical diagnosis is based on development of any twodisease components within the combined classic and adjunct triad of urticarial eruption, intestinal dysfunction and enamel hypoplasia [9].

\section{Case presentation}

The patient was born (birthweight $3830 \mathrm{~g}$ ) by caesarean section to a 26-year old mother with three previous gestations including two fullterm deliveries and one aborted fetus. Parents came from Turkey and were unrelated. The family had no history for autoimmune diseases. Mother's one-week-old sister and four-month-old brother had died for unknown reasons. Patient's paternal cousin had presented with heart and kidney anomalies and a history of frequent pneumonias.

At the age of 8 years, the patient was admitted to the Pediatric Immunology Department of the Uludag University Medical Faculty because of recurrent mucosal and cutaneous candidiasis since infancy. At the age of 10 years, he developed vitiligo, alopecia, and arthralgia of knee joints. Arthralgia was responsive to non-steroid anti-inflammatory treatment. Concurrently, the patient had had recurrent episodes of watery diarrhea and abdominal distension for one year and dry eyes and mouth for six months. Ophthalmological examination was normal.

Homozygous R257X AIRE gene mutation was detected in patient's DNA (Table 1). Abs screening revealed anti-IFN- $\omega$ specificities. Direct positivity for anti-tryptophan hydroxylase (TPH) and anti-aromatic Lamino-acid decarboxylase (AADC) Abs confirmed the diagnosis of APECED and autoimmune enteropathy. Furthermore, anti-52 kDa Ro/ SS-A (RO52) antibodies associated with high rheumatoid factor titers supported the diagnosis of Sjögren-like syndrome. Direct Coombs test was positive associated with low hemoglobin values and high reticulocyte count indicating autoimmune hemolytic anemia (Table 1).

\section{Discussion}

In this manuscript we present the clinical, immunological and genetic features of a new case of APECED and review in the literature from 2000 to date a Turkish APECED series of patients, mostly diagnosed on clinical findings [29-45]. Results of the analysis were compared with those retrieved on Finnish, Sardinian and North/South American cohorts $[9,10,28]$ based on classic versus novel Ferre/ 
Table 2

Clinical and genetic features of 23 Turkish APECED patients including the present case report.

\begin{tabular}{|c|c|c|c|c|c|c|c|}
\hline Turkish Patients & Sex & $\begin{array}{l}\text { Age at referral } \\
\text { (years, } \\
\text { months) }\end{array}$ & $\begin{array}{l}\text { Age of first } \\
\text { symptom (years, } \\
\text { months) }\end{array}$ & AIRE mutation & $\begin{array}{l}\text { Major clinical manifestations } \\
\text { related to APECED }\end{array}$ & Other clinical manifestations & References \\
\hline 1 & Female* & 17 & 5 & $\begin{array}{l}\text { EXON 1: homozygous } \\
\text { p.R15H (c. } 44 \mathrm{G}>\text { A) }\end{array}$ & $\begin{array}{l}\text { Hypoparathyroidism Addison's } \\
\text { disease } \\
\text { CMC (esophageal candidiasis) }\end{array}$ & $\begin{array}{l}\text { Autoimmune thyroiditis Ovarian } \\
\text { insufficiency } \\
\text { Autoimmune hepatitis } \\
\text { Hepatopulmonary } \\
\text { hypoxemia } \\
\text { (central cyanosis, } \\
\text { digital clubbing, } \\
\text { portal hypertension) }\end{array}$ & [29] \\
\hline 2 & Male * & 25 & 9 & $\begin{array}{l}\text { EXON 1: homozygous } \\
\text { p.R15H (c. } 44 \mathrm{G}>\text { A) }\end{array}$ & $\begin{array}{l}\text { Hypoparathyroidism } \\
\text { CMC }\end{array}$ & & [29] \\
\hline 3 & & & & $\begin{array}{l}\text { EXON 6: homozygous } \\
\text { p.R257X } \\
(\text { c.769C > T) }\end{array}$ & $\begin{array}{l}\text { Hypoparathyroidism } \\
\text { CMC }\end{array}$ & $\begin{array}{l}\text { Alopecia } \\
\text { Autoimmune thyroiditis } \\
\text { Pernicious anemia } \\
\text { Type } 1 \text { diabetes mellitus }\end{array}$ & {$[30]$} \\
\hline 4 & & & & $\begin{array}{l}\text { EXON 6: heterozygous } \\
\text { p.R257X } \\
\text { (c.769C > T) } \\
\text { EXON 11: heterozygous } \\
\text { p.C457fs } \\
\text { (c.1370-1371 insG) }\end{array}$ & $\begin{array}{l}\text { Hypoparathyroidism } \\
\text { Addison's disease } \\
\text { CMC }\end{array}$ & $\begin{array}{l}\text { Nail dystrophy } \\
\text { Alopecia } \\
\text { Autoimmune hepatitis } \\
\text { Vitiligo } \\
\text { Autoimmune thyroiditis } \\
\text { Pernicious anemia } \\
\text { Keratitis }\end{array}$ & [30] \\
\hline 5 & Male** & 20 & 1 & $\begin{array}{l}\text { EXON 14: homozygous } \\
\text { p.P539L } \\
\text { INTRON 9: } \\
\text { 11,107 G > A }\end{array}$ & $\begin{array}{l}\text { Addison's disease } \\
\text { CMC } \\
\text { Hypoparathyroidism } \\
\text { (urolithiasis, nephrocalcinosis) }\end{array}$ & $\begin{array}{l}\text { Alopecia universalis } \\
\text { Ectodermal dystrophy } \\
\text { Pernicious anemia } \\
\text { Vitiligo } \\
\text { Pneumonia } \\
\text { Hypergonadotropic hypogonadism } \\
\text { Preclinical autoimmune thyroiditis }\end{array}$ & {$[31]$} \\
\hline 6 & Female ${ }^{* *}$ & 17 & 3 & $\begin{array}{l}\text { EXON 14: homozygous } \\
\text { p.P539L } \\
\text { INTRON 9: } \\
\text { 11,107 G > A }\end{array}$ & $\begin{array}{l}\text { hypoparathyroidism } \\
\text { Addison's disease } \\
\text { Oral CMC }\end{array}$ & $\begin{array}{l}\text { Alopecia areata } \\
\text { Ectodermal dystrophy } \\
\text { Autoimmune thyroiditis } \\
\text { Diabetes mellitus } \\
\text { Hypopituitarism (retarded growth } \\
\text { and pubertal development) } \\
\text { Non suppurative otitis }\end{array}$ & [31] \\
\hline 7 & Female & 9 & 8 & $\begin{array}{l}\text { EXON 2: homozygous } \\
\text { p.Tyr90-Arg92del } \\
\text { (C.267-275del); } \\
\text { C.261 G > T } \\
\text { homozygous } \\
\text { silent variation; } \\
\text { c.264 G > A } \\
\text { homozygous } \\
\text { silent variation } \\
\text { EXON 6: homozygous } \\
\text { c.681C > T (rs } \\
\text { 1,055,311) } \\
\text { polymorphism }\end{array}$ & $\begin{array}{l}\text { Oral CMC } \\
\text { Hypoparathyroidism }\end{array}$ & $\begin{array}{l}\text { Ectodermal dysplasia } \\
\text { Ectodermal dystrophy of nails } \\
\text { Pernicious anemia } \\
\text { Alopecia } \\
\text { Atrophc gastritis } \\
\text { Retinal pigmentary changes } \\
\text { (pigment epithelial atrophy, } \\
\text { decreased visual acuity) }\end{array}$ & {$[32]$} \\
\hline 8 & Male & 8.11 & 3 & $\begin{array}{l}\text { EXON 6: homozygous } \\
\text { p.R257X } \\
(c .769 \mathrm{C}>\mathrm{T})\end{array}$ & CMC & $\begin{array}{l}\text { Ectodermal dystrophy } \\
\text { Vitiligo } \\
\text { Alopecia } \\
\text { Arthralgia } \\
\text { Autoimmune enteropathy } \\
\text { Hemolytic anemia } \\
\text { Undifferentiated connective tissue } \\
\text { disease } \\
\text { Preclinical Sjögren syndrome }\end{array}$ & $\begin{array}{l}\text { Present } \\
\text { study }\end{array}$ \\
\hline 9 & Female & 33 & 32 & $\begin{array}{l}\text { not tested } \\
\text { (clinical diagnosis) }\end{array}$ & $\begin{array}{l}\text { CMC } \\
\text { (candida esophagitis) } \\
\text { Antral gastritis } \\
\text { Addison's disease }\end{array}$ & $\begin{array}{l}\text { Ectodermal dystrophy } \\
\text { Primary hypogonadism }\end{array}$ & {$[33]$} \\
\hline 10 & Female & 20 & 9 & $\begin{array}{l}\text { not tested } \\
\text { (clinical diagnosis) }\end{array}$ & $\begin{array}{l}\text { Hypoparathyroidism } \\
\text { Addison's disease } \\
\text { Oral CMC }\end{array}$ & $\begin{array}{l}\text { Ectodermal dystrophy } \\
\text { Suspected pericarditis } \\
\text { Upper respiratory infections }\end{array}$ & [34] \\
\hline 11 & Female & 18 & 18 & $\begin{array}{l}\text { not tested } \\
\text { (clinical diagnosis) }\end{array}$ & $\begin{array}{l}\text { Hypoparathyroidism } \\
\text { Addison's disease } \\
\text { Oral CMC }\end{array}$ & $\begin{array}{l}\text { Ectodermal dystrophy } \\
\text { Hyperpigmentation }\end{array}$ & [35] \\
\hline 12 & Female & 31 & 8 & $\begin{array}{l}\text { EXON 6: homozygous } \\
\text { p.R257X (c.769C > T) }\end{array}$ & $\begin{array}{l}\text { Hypoparathyroidism } \\
\text { CMC }\end{array}$ & $\begin{array}{l}\text { Vitiligo } \\
\text { Dental enamel hypoplasia Nail } \\
\text { Dystrophy }\end{array}$ & [36] \\
\hline
\end{tabular}


Table 2 (continued)

\begin{tabular}{|c|c|c|c|c|c|c|c|}
\hline Turkish Patients & Sex & $\begin{array}{l}\text { Age at referral } \\
\text { (years, } \\
\text { months) }\end{array}$ & $\begin{array}{l}\text { Age of first } \\
\text { symptom (years, } \\
\text { months) }\end{array}$ & AIRE mutation & $\begin{array}{l}\text { Major clinical manifestations } \\
\text { related to APECED }\end{array}$ & Other clinical manifestations & References \\
\hline 13 & Female & 29 & 3 & negative & $\begin{array}{l}\text { Hypoparathyroidism } \\
\text { CMC }\end{array}$ & $\begin{array}{l}\text { Ectodermal dysplasia } \\
\text { (nail dystrophy) } \\
\text { Alopecia }\end{array}$ & [36] \\
\hline 14 & & & & not available & (Autoimmune?) Adrenalitis & $\begin{array}{l}\text { Vitiligo } \\
\text { Hypothyroidism }\end{array}$ & [37] \\
\hline 15 & Male & 14 & 12 & $\begin{array}{l}\text { EXON 8: homozygous } \\
\text { c.964del13 }\end{array}$ & $\begin{array}{l}\text { Hypoparathyroidism } \\
\text { Addison's disease }\end{array}$ & Psoriasis vulgaris & [38] \\
\hline 16 & Male & 41 & 41 & $\begin{array}{l}\text { not tested } \\
\text { (clinical diagnosis) }\end{array}$ & $\begin{array}{l}\text { CMC } \\
\text { Addison's disease }\end{array}$ & $\begin{array}{l}\text { Hypogonadotropic hypogonadism } \\
\text { (HH) } \\
\text { Alopecia } \\
\text { Vitiligo } \\
\text { Chronic urticaria } \\
\text { Chronic active hepatitis } \\
\text { Malabsorption }\end{array}$ & [39] \\
\hline 17 & Male & 12 & 12 & $\begin{array}{l}\text { not tested } \\
\text { (clinical diagnosis) }\end{array}$ & $\begin{array}{l}\text { Hypoparathyroidism } \\
\text { Oral CMC }\end{array}$ & $\begin{array}{l}\text { Amelogenesis imperfecta } \\
\text { Tooth eruption delay } \\
\text { Dental caries }\end{array}$ & [40] \\
\hline 18 Azerbaijan & & & & $\begin{array}{l}\text { Introns 1-4: } \\
\text { homozygous } \\
\text { IVS1-IVS4 }\end{array}$ & $\begin{array}{l}\text { Hypoparathyroidism } \\
\text { Addison's disease } \\
\text { CMC }\end{array}$ & $\begin{array}{l}\text { Alopecia } \\
\text { Malabsorption }\end{array}$ & [41] \\
\hline 19 & Female & 15 & 15 & $\begin{array}{l}\text { not tested } \\
\text { (clinical diagnosis) }\end{array}$ & $\begin{array}{l}\text { Hypoparathyroidism } \\
\text { Oral CMC }\end{array}$ & Epilepsy & [42] \\
\hline 20 & Female & 17 & 17 & $\begin{array}{l}\text { not tested } \\
\text { (clinical diagnosis) }\end{array}$ & $\begin{array}{l}\text { Addison's disease } \\
\text { Oral CMC } \\
\text { Hypoparathyroidism }\end{array}$ & Ectodermal dystrophy in fingernails & [43] \\
\hline 21 & Female $^{\wedge}$ & 8 & 5 & $\begin{array}{l}\text { EXON 2:homozygous } \\
\text { p.W78R (c.232 T > C) }\end{array}$ & $\begin{array}{l}\text { Hypoparathyroidism } \\
\text { Addison's disease }\end{array}$ & & [44] \\
\hline 22 & Female^ & 4.6 & 4.6 & $\begin{array}{l}\text { EXON 2: homozygous } \\
\text { p.W78R }(c .232 \mathrm{~T}>\mathrm{C})\end{array}$ & Hypoparathyroidism & & [44] \\
\hline 23 & Male & 6 & 3 & $\begin{array}{l}\text { not tested } \\
\text { (clinical diagnosis) }\end{array}$ & $\begin{array}{l}\text { Hypoparathyroidism } \\
\text { Addison's disease } \\
\text { CMC }\end{array}$ & & [45] \\
\hline
\end{tabular}

***, siblings.

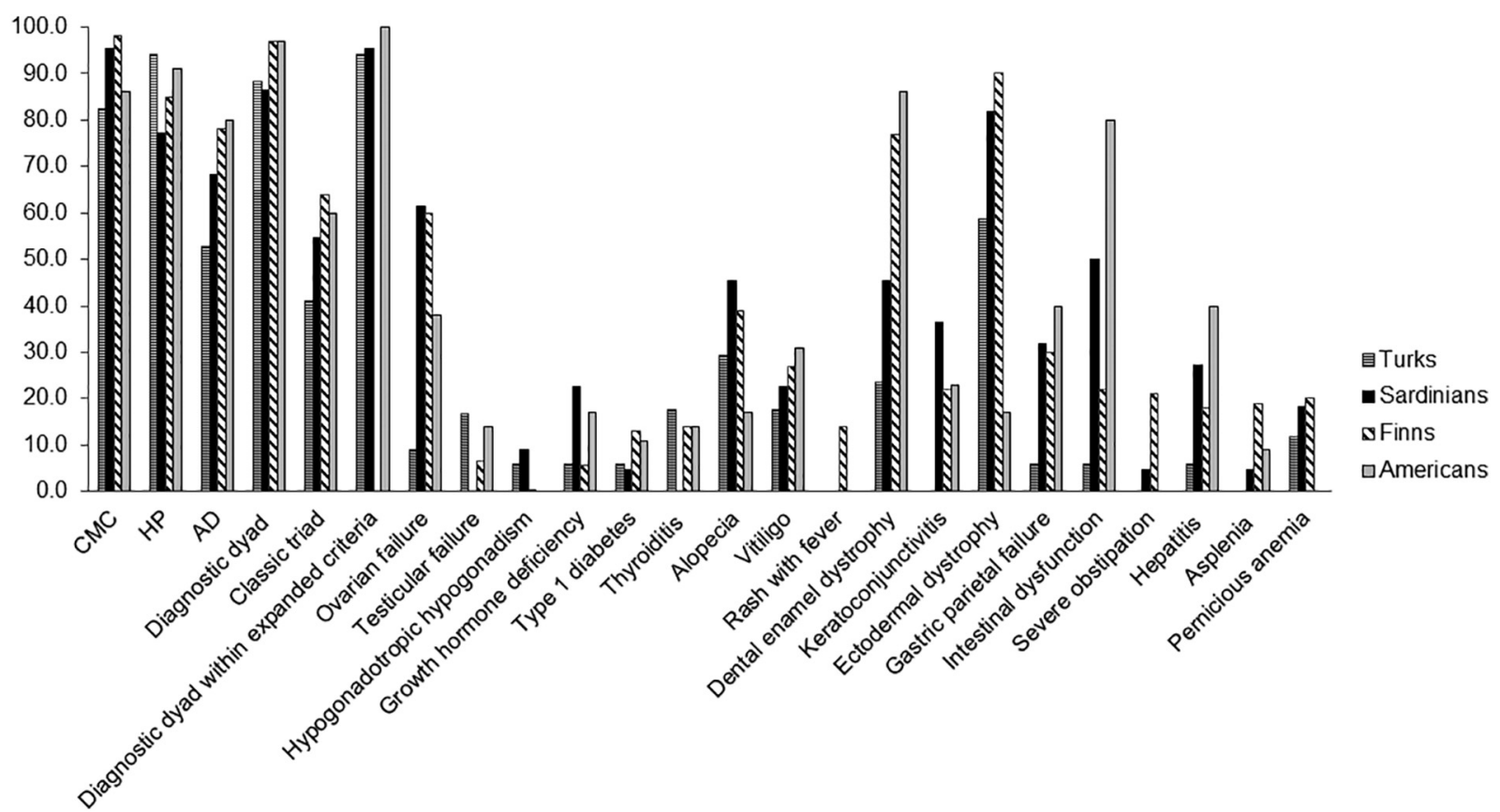

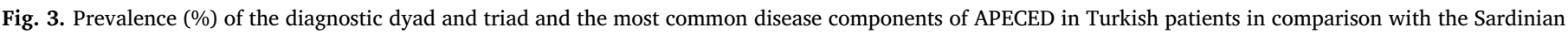
series published by Meloni et al. (2012) [10], the Finnish series by Perheentupa et al. (2006) [28] and the American series by Ferre et al. (2016) [9].

Lionakis diagnostic criteria [10]. Our Turkish patient presented with merely one classic clinical manifestation (CMC), and only later developed other autoimmune manifestations over the years. The presence of the homozygous R257X mutation of the AIRE gene confirmed the diagnosis of APECED syndrome based on the classic revised criteria [7]. Interestingly, circulating TPH, AADC and IFN- $\omega$ Abs were detected at high titers. In this respect, the presence of cytokine Abs strongly correlates with CMC according to APECED epidemiological investigations 
[6]. Presence of TPH and AADC Abs confirmed the diagnosis of autoimmune enteropathy in the patient. Autoantibodies against TPH and AADC target two different enzymes important for monoamine synthesis and present in enteric and central nervous system serotoninergic cells [6].

This patient is part of a series of 23 Turkish APECED patients (female/male ratio: 1.71; median age at referral 17 years; range 4.6-41) with early disease onset (median 8 years, age-range 1-41, based on the appearance of the first component of the triad) and severe phenotype (on average, 5.17 manifestations/patient) (Figs. 1,2). Six out of 23 patients were born from 4 consanguineous marriages out of the total 18 marriages [31,32,39,44]. The presence of another case with APECED in the same family was reported in 3 families with a frequency of $16.6 \%$ $[29,31,44]$.

The penetrance of APECED is $100 \%$, i.e. when two variant AIRE alleles are inherited, the patient will inevitably develop the disorder. Patient's stopgain c.769C > T (p.Arg257Ter) leads to a truncated 256 protein lacking both PHD domains, impairing its multimerization and transactivation activity [46]. The R257X mutation was previously identified as the Finnish major mutation, reported in $89 \%$ of FinnAPECED chromosomes [8,47].

This was the prevalent mutation within genotyped Turkish APECED patients since found in $30.7 \%$ (4/13) of patients in comparison to the other genotypes, each represented in $2 / 13$ patients. This finding confirms the cross-ethnicity nature of the mutation already reported in various populations [21,48]. Of note, in the American series [9], 28.6\% of patients were homozygous for the AIRE mutation c.967_979del 13 (p.L323SfsX51), only 2.9\% were homozygous for the prevalent Finnish genotype c.769C > T while $11.4 \%$ were homozygous for wild-type AIRE.

The analysis of the overall clinical features (Table 2) indicates the absence of a clear phenotype/genotype correlation in Turkish APECED patients [8-10,28]. Regarding the clinical phenotypes, the classic triad was present in $39.1 \%$ of total patients, $87 \%$ manifested $2 / 3$ major manifestations. Considering patients diagnosed before the age of 30 years, of 17 Turkish APECED patients $82.4 \%$ had CMC (9/11 females, 5/6 males), while CMC was seen in $95.5 \%$ of Sardinian [10], $98 \%$ of Finnish [28] and 86\% of American patients [9] (Fig. 3). Of these 17 Turkish APECED patients, $94.1 \%$ had HP (11/11 females, 5/6 males), while it was reported in $73.3 \%$ of Sardinians [10], $85 \%$ of Finnish [28] and 91\% of American patients [9] (Fig. 3). Of these series, $52.9 \%$ had $\mathrm{AD}(6 / 11$ females and $3 / 6$ males), while present in $68.2 \%$ of Sardinian [10], 78\% of Finnish [28] and 80\% of American patients [9] (Fig. 3).

Interestingly, several non-endocrine manifestations were reported in the present series.

(Fig. 1) although at lower frequencies than in American APECED cohort, where these were present in $40-80 \%$ of patients in early life. Among non-endocrine autoimmune features, urticarial eruption, hepatitis, gastritis, intestinal dysfunction, pneumonitis, Sjögren syndrome were represented in the Turkish patients. Indeed non-endocrine secondary diseases appeared later than the triad symptoms as opposite to American APECED patients (Fig. 2); nevertheless, the low number of affected patients in respect to the secondary manifestations may infer the analysis in the present series. Interestingly, in the overall Turkish series, HP had the earlier mean age of appearance in life than CMC, frequently reported as first symptom [49].

Of note, we verified that the diagnostic dyad within expanded criteria allowed an earlier diagnosis in 3/16 Turkish patients (18.8\%) and in $5 / 21$ Sardinian patients $(23.8 \%)$ throughout a longitudinal evaluation based on the appearance of clinical characteristics until the age of 30 years (Fig. 3, Supplementary Fig. 1). Additionally, in the limited longitudinal data related to the Finnish series published by Perheentupa et al. [28] an earlier diagnosis could have been possible even in 5/13 Finnish APECED patients (38.55\%). Data could also be retrieved by the analysis of the Finnish series published by Merenmies and Tarkkanen et al. [50] where, based on the appearance of chronic bilateral keratitis, 9/17 patients (52.9\%) could have had an earlier diagnosis of APECED. Thus, it is important to remember the high incidence of some non-endocrine manifestations such as intestinal dysfunction and ectodermal dystrophies [24,50,51]. Clearly, as stated above, our analysis on the Turkish series is limited by its retrospective nature since data are derived from the available scientific literature on APECED. Further, interpretation of results derived from the comparative applicability of the classic versus Ferre/Lionakis criteria for an earlier APECED diagnosis would certainly benefit from future examination of extended cohorts.

\section{Conclusions}

Genetic testing and counseling of APECED patients' parents and relatives will aid in expedited diagnosis. However, APECED patients appear nowadays to be among the most unsatisfied patient groups, with limited success gained by the strategy of early diagnosis leading to hormone replacement therapy alone [26,52]. Future investigations will clarify whether the novel Ferre/Lionakis criteria [9] will indeed allow for expedited diagnosis, and whether early-onset immunomodulatory treatments could have the potential to avoid severe disease complications and improve patient satisfaction and/or prognosis.

\section{Conflict of interest disclosure}

None.

\section{Funding source}

This study was supported by the Italian Ministry of Health Ricerca Corrente 201702 P003967.

Supplementary data to this article can be found online at https:// doi.org/10.1016/j.clim.2018.06.012.

\section{Acknowledgments}

FIRS Laboratories, RSR Ltd. (Cardiff, UK) performed Abs tests including IFN- $\omega, 210 \mathrm{H}, 17 \alpha \mathrm{OH}, \mathrm{p} 450 \mathrm{scc}$, TPH and AADC Abs.

The following are the supplementary data related to this article.

\section{References}

[1] H. Al-Mousa, B. Al-Saud, Primary immunodeficiency diseases in highly consanguineous populations from Middle East and North Africa: epidemiology, diagnosis, and care, Front. Immunol. 8 (2017) 678, , http://dx.doi.org/10.3389/fimmu. 2017.00678.

[2] R.E. Schmidt, B. Grimbacher, T. Witte, Autoimmunity and primary immunodeficiency: two sides of the same coin? Nat. Rev. Rheumatol. 14 (2017) 7-18, http://dx.doi.org/10.1038/nrrheum.2017.198.

[3] A. Fierabracci, Recent insights into the role and molecular mechanisms of the autoimmune regulator (AIRE) gene in autoimmunity, Autoimmun. Rev. 10 (2011) 137-143, http://dx.doi.org/10.1016/j.autrev.2010.08.019.

[4] F. Eddahri, G. Oldenhove, S. Denanglaire, J. Urbain, O. Leo, F. Andris, CD4+ $\mathrm{CD} 25+$ regulatory $\mathrm{T}$ cells control the magnitude of T-dependent humoral immune responses to exogenous antigens, Eur. J. Immunol. 36 (2006) 855-863, http://dx doi.org/10.1002/eji.200535500.

[5] E. Kekäläinen, H. Tuovinen, J. Joensuu, M. Gylling, R. Franssila, N. Pöntynen, K. Talvensaari, J. Perheentupa, A. Miettinen, T.P. Arstila, A defect of regulatory T cells in patients with autoimmune polyendocrinopathy-candidiasis-ectodermal dystrophy, J. Immunol. 178 (2007) 1208-1215, http://dx.doi.org/10.4049/ jimmunol.178.2.1208.

[6] N. Landegren, D. Sharon, E. Freyhult, Å. Hallgren, D. Eriksson, P.H. Edqvist, S. Bensing, J. Wahlberg, L.M. Nelson, J. Gustafsson, E.S. Husebye, M.S. Anderson, M. Snyder, O. Kämpe, Proteome-wide survey of the autoimmune target repertoire in autoimmune polyendocrine syndrome type 1, Sci. Rep. 6 (2016) 20104, , http://dx. doi.org/10.1038/srep20104.

[7] E.S. Husebye, J. Perheentupa, R. Rautemaa, O. Kämpe, Clinical manifestations and management of patients with autoimmune polyendocrine syndrome type I, J. Intern. Med. 265 (2009) 514-529, http://dx.doi.org/10.1111/j.1365-2796.2009. 02090.x.

[8] P. Ahonen, S. Myllärniemi, I. Sipilä, J. Perheentupa, Clinical variation of autoimmune polyendocrinopathy-candidiasis-ectodermal dystrophy (APECED) in a series of 68 patients, N. Engl. J. Med. 322 (1990) 1829-1836, http://dx.doi.org/10. 1056/NEJM199006283222601. 
[9] E.M. Ferre, S.R. Rose, S.D. Rosenzweig, P.D. Burbelo, K.R. Romito, J.E. Niemela, L.B. Rosen, T.J. Break, W. Gu, S. Hunsberger, S.K. Browne, A.P. Hsu, S. Rampertaap, M. Swamydas, A.L. Collar, H.H. Kong, C.R. Lee, D. Chascsa, T. Simcox, A. Pham, A. Bondici, M. Natarajan, J. Monsale, D.E. Kleiner, M. Quezado, I. Alevizos, N.M. Moutsopoulos, L. Yockey, C. Frein, A. Soldatos, K.R. Calvo, J. Adjemian, M.N. Similuk, D.M. Lang, K.D. Stone, G. Uzel, J.B. Kopp, R.J. Bishop, S.M. Holland, K.N. Olivier, T.A. Fleisher, T. Heller, K.K. Winer, M.S. Lionakis, Redefined clinical features and diagnostic criteria in autoimmune polyendocrinopathy-candidiasisectodermal dystrophy, JCI Insight 18 (2016) e88782, http://dx.doi.org/10.1172/ jci.insight. 88782 .

[10] A. Meloni, N. Willcox, A. Meager, M. Atzeni, A.S. Wolff, E.S. Husebye, M. Furcas, M.C. Rosatelli, A. Cao, M. Congia, Autoimmune polyendocrine syndrome type 1: an extensive longitudinal study in Sardinian patients, J. Clin. Endocrinol. Metab. 97 (2012) 1114-1124, http://dx.doi.org/10.1210/jc.2011-2461.

[11] J. Zlotogora, M.S. Shapiro, Polyglandular autoimmune syndrome type I among Iranian Jews, J. Med. Genet. 29 (1992) 824-826.

[12] A.S. Wolff, M.M. Erichsen, A. Meager, N.F. Magitta, A.G. Myhre, J. Bollerslev, K.J. Fougner, K. Lima, P.M. Knappskog, E.S. Husebye, Autoimmune polyendocrine syndrome type 1 in Norway: phenotypic variation, autoantibodies, and novel mutations in the autoimmune regulator gene, J. Clin. Endocrinol. Metab. 92 (2007) 595-603, http://dx.doi.org/10.1210/jc.2006-1873.

[13] M. Dominguez, E. Crushell, T. Ilmarinen, E. McGovern, S. Collins, B. Chang, P. Fleming, A.D. Irvine, D. Brosnahan, I. Ulmanen, N. Murphy, C. Costigan, Autoimmune polyendocrinopathy-candidiasis-ectodermal dystrophy (APECED) in the Irish population, J. Pediatr. Endocrinol. Metab. 19 (2006) 1343-1352.

[14] N.F. Magitta, M. Pura, A.S. Bøe Wolff, P. Vanuga, A. Meager, P.M. Knappskog, E.S. Husebye, Autoimmune polyendocrine syndrome type I in Slovakia: relevance of screening patients with autoimmune Addison's disease, Eur. J. Endocrinol. 158 (2008) 705-709, http://dx.doi.org/10.1530/EJE-07-0843.

[15] E.M. Orlova, A.M. Bukina, E.S. Kuznetsova, M.A. Kareva, E.U. Zakharova, V.A. Peterkova, I.I. Dedov, Autoimmune polyglandular syndrome type 1 in Russian patients: clinical variants and autoimmune regulator mutations, Horm. Res. Paediatr. 73 (2010) 449-457, http://dx.doi.org/10.1159/000313585.

[16] E.M. Orlova, L.S. Sozaeva, M.A. Kareva, B.E. Oftedal, A.S.B. Wolff, L. Breivik, E.Y. Zakharova, O.N. Ivanova, O. Kämpe, I.I. Dedov, P.M. Knappskog, V.A. Peterkova, E.S. Husebye, Expanding the phenotypic and genotypic landscape of autoimmune Polyendocrine syndrome type 1, J. Clin. Endocrinol. Metab. 102 (2017) 3546-3556, http://dx.doi.org/10.1210/jc.2017-00139.

[17] S.H. Pearce, T. Cheetham, H. Imrie, B. Vaidya, N.D. Barnes, R.W. Bilous, D. Carr, K. Meeran, N.J. Shaw, C.S. Smith, A.D. Toft, G. Williams, P. Kendall-Taylor, A common and recurrent 13-bp deletion in the autoimmune regulator gene in British kindreds with autoimmune polyendocrinopathy type 1, Am. J. Hum. Genet. 63 (1998) 1675-1684, http://dx.doi.org/10.1086/302145.

[18] A.G. Myhre, M. Halonen, P. Eskelin, O. Ekwall, H. Hedstrand, F. Rorsman, O. Kämpe, E.S. Husebye, Autoimmune polyendocrine syndrome type 1 (APS I) in Norway, Clin. Endocrinol. 54 (2001) 211-217, http://dx.doi.org/10.1046/j.13652265.2001.01201.x

[19] M. Neufeld, N.K. Maclaren, R.M. Blizzard, Two types of autoimmune Addison's disease associated with different polyglandular autoimmune (PGA) syndromes, Medicine (Baltimore) 60 (1981) 355-362.

[20] K.T. Podkrajsek, N. Bratanic, C. Krzisnik, T. Battelino, Autoimmune regulator-1 messenger ribonucleic acid analysis in a novel intronic mutation and two additional novel AIRE gene mutations in a cohort of autoimmune polyendocrinopathy-candidiasis-ectodermal dystrophy patients, J. Clin. Endocrinol. Metab. 90 (2005) 4930-4935, http://dx.doi.org/10.1210/jc.2005-0418.

[21] B. Stolarski, E. Pronicka, L. Korniszewski, A. Pollak, G. Kostrzewa, E. Rowińska, P. Włodarski, A. Skórka, M. Gremida, P. Krajewski, R. Ploski, Molecular background of polyendocrinopathy-candidiasis-ectodermal dystrophy syndrome in a polish population: novel AIRE mutations and an estimate of disease prevalence, Clin. Genet. 70 (2006) 348-354, http://dx.doi.org/10.1111/j.1399-0004.2006.00690.x.

[22] M. Valenzise, A. Fierabracci, M. Cappa, P. Porcelli, R. Barcellona, F. De Luca, S. Barollo, S. Garelli, C. Betterle, Autoimmune polyendocrinopathy-candidiasis-ectodermal dystrophy: report of seven additional sicilian patients and overview of the overall series from sicily, Horm. Res. Paediatr. 82 (2014) 127-132, http://dx.doi. org $/ 10.1159 / 000363537$

[23] Ø. Bruserud, B.E. Oftedal, N. Landegren, M.M. Erichsen, E. Bratland, K. Lima, A.P. Jørgensen, A.G. Myhre, J. Svartberg, K.J. Fougner, Å. Bakke, B.G. Nedrebø, B. Mella, L. Breivik, M.K. Viken, P.M. Knappskog, M.C. Marthinussen, K. Løvås, O. Kämpe, A.B. Wolff, E.S. Husebye, A longitudinal follow-up of autoimmune Polyendocrine syndrome type 1, J. Clin. Endocrinol. Metab. 101 (2016) 2975-2983, http://dx.doi.org/10.1210/jc.2016-1821.

[24] N. Kluger, M. Jokinen, A. Lintulahti, K. Krohn, A. Ranki, Gastrointestinal immunity against tryptophan hydroxylase-1, aromatic L-amino-acid decarboxylase, AIE-75, villin and Paneth cells in APECED, Clin. Immunol. 158 (2015) 212-220, http://dx. doi.org/10.1016/j.clim.2015.03.012.

[25] B.E. Oftedal, A. Hellesen, M.M. Erichsen, E. Bratland, A. Vardi, J. Perheentupa, E.H. Kemp, T. Fiskerstrand, M.K. Viken, A.P. Weetman, S.J. Fleishman, S. Banka, W.G. Newman, W.A. Sewell, L.S. Sozaeva, T. Zayats, K. Haugarvoll, E.M. Orlova, J. Haavik, S. Johansson, P.M. Knappskog, K. Løvås, A.S. Wolff, J. Abramson, E.S. Husebye, Dominant mutations in the autoimmune regulator AIRE are associated with common organ-specific autoimmune diseases, Immunity 42 (2015) 1185-1196, http://dx.doi.org/10.1016/j.immuni.2015.04.021.

[26] K. Kisand, P. Peterson, Autoimmune polyendocrinopathy candidiasis ectodermal dystrophy, J. Clin. Immunol. 35 (2015) 463-478, http://dx.doi.org/10.1007/ s10875-015-0176-y.

[27] H.D. Ochs, D. Petroni, From clinical observations and molecular dissection to novel therapeutic strategies for primary immunodeficiency disorders, Am. J. Med. Genet.
A 176 (2018) 784-803, http://dx.doi.org/10.1002/ajmg.a.38480

[28] J. Perheentupa, Autoimmune polyendocrinopathy-candidiasis-ectodermal dystrophy, J. Clin. Endocrinol. Metab. 91 (2006) 2843-2850, http://dx.doi.org/10. 1210/jc. 2005-2611.

[29] F. Celmeli, A. Kocabas, I.A. Isik, M. Parlak, K. Kisand, S. Ceylaner, D. Turkkahraman, Unexplained cyanosis caused by hepatopulmonary syndrome in a girl with APECED syndrome, J. Pediatr. Endocrinol. Metab. 30 (2017) 365-369, http://dx.doi.org/10.1515/jpem-2016-0276.

[30] C. Mazza, F. Buzi, F. Ortolani, A. Vitali, L.D. Notarangelo, G. Weber, R. Bacchetta A. Soresina, V. Lougaris, N.A. Greggio, A. Taddio, S. Pasic, M. de Vroede, M. Pac, S.S. Kilic, S. Ozden, R. Rusconi, S. Martino, D. Capalbo, M. Salerno, C. Pignata, G. Radetti, G. Maggiore, A. Plebani, L.D. Notarangelo, R. Badolato, Clinical heterogeneity and diagnostic delay of autoimmune polyendocrinopathy-candidiasisectodermal dystrophy syndrome, Clin. Immunol. 139 (2011) 6-11, http://dx.doi org/10.1016/j.clim.2010.12.021.

[31] T. Meyer, V. Ruppert, K. Karatolios, B. Maisch, Hereditary long QT syndrome due to autoimmune hypoparathyroidism in autoimmune polyendocrinopathy-candidiasisectodermal dystrophy syndrome, J. Electrocardiol. 40 (2007) 504-509, http://dx. doi.org/10.1016/j.jelectrocard.2006.12.013.

[32] H. Akil, A.D. Bulus, N. Andiran, P.S. Veber, S. Keskin, A case of autoimmune polyendocrine syndrome type 1 with ocular findings and unique AIRE gene defect, J. Clin. Ophthal. Res. 4 (2016) 37-39, http://dx.doi.org/10.4103/2320-3897. 174414.

[33] I. Kuzu, S.S. Zuhur, F.Y. Öztürk, S. Karatas, H.M. Özkaya, M.M. Canat, Y. Altuntas, A case with APECED syndrome, Endocr. Abstr. 35 (2014) P221 https://doi.org/10. 1530/endoabs.35.P221.

[34] N.O. Kutbay, B.S. Yurekli, M. Yaman, M. Erdogan, S. Cetinkalp, F. Saygili, S. Darcan, G. Ozgen, A case of polyglandular autoimmune syndrome type 1 with hypercalcemia and hypotension, poster presented at ECE2015 Dublin, Theatr. Irel.

[35] A. Alpcan, B. Eris, S. A. Durmaz, A. Cifci, I. Kalan, A case of childhood autoimmune polyglandular syndrome type 1, poster presented at ECE2015 Dublin, Theatr. Irel.

[36] M. Güçlü, H. Cangül, C. Ersoy, Strong, similarities in Turkish and European patients diagnosed with APECED syndrome, Turk. J. Endocrinol. Metab. 19 (2015) 89-92, http://dx.doi.org/10.4274/tjem.2987.

[37] H.E. Barıs, A. Kıykım, E. Nain, A.O. Özen, E. Karakoç-Aydıner, S. Barıs, The plethora, clinical manifestations and treatment options of autoimmunity in patients with primary immunodeficiency, Turk. Pediatri. Ars. 51 (2016) 186-192, http://dx. doi.org/10.5152/TurkPediatriArs.2016.3928.

[38] A. Cayir, R.I. Engin, M.I. Turan, E. Pala, Psoriasis vulgaris and autoimmune polyendocrine syndrome type I: a case report, J. Pediatr. Endocrinol. Metab. 27 (2014) 791-793, http://dx.doi.org/10.1515/jpem-2013-0472.

[39] T. Bayraktaroğlu, H. Boztepe, S. Yarman, R. Tanakol, F. Alagöl, Geç Ortaya Çıkan tip 1 Otoimmün Poliglandüler Yetersizlik Sendromlu Bir Olgu A case of late presented with autoimmune polyglandular syndrome type 1, Turkiye Klinikleri J. Med. Sci. 27 (2007) 778-782

[40] Y. Yıldırım, S. Şener, M.S. Botsalı, G. Tosun, Apeced sendromu: olgu bildirimi, Acta Odontol. Turc. 30 (2013) 90-92.

[41] D. Cihakova, K. Trebusak, M. Heino, V. Fadeyev, A. Tiulpakov, T. Battelino, A. Tar, Z. Halász, P. Blümel, S. Tawfik, K. Krohn, J. Lebl, P. Peterson, the MEWPE-APECED Study Group, Novel AIRE mutations and P450 cytochrome autoantibodies in central and eastern European patients with APECED, Hum. Mutat. 18 (2001) 225-232, http://dx.doi.org/10.1002/humu.1178.

[42] M. Ergüven, Ü. Akyüz, S. Güven, F. Laloğlu, O. Bilgic,, Konvülziyon ve Karpopedal Spazm ile Acil Servise Başvuran Tip 1 Otoimmün Poliglandüler Sendrom ve heliotropik Raş Birlikteliği, Zeynep Kamil Tip Bülteni 39 (2008) 203-205.

[43] D. Gökalp, S. Arikan, M. Bahçeci, A.K. Tuzcu, M. Ali Kaplan, Hipokalsemi ile Bașvuran Otoimmün Poliglanduler Sendrom (OPS) Tip 1 Olgusu, Turkiye Klinikleri J. Endocrin. 3 (2008) 26-28.

[44] I. Esen, A. Kara, S. Ceylaner, Otoimmün Poliendokrinopati-Kandidiazis-Ektoderma Distrofi (APECED) Sendrom'lu İki Kız Kardeş, Firat Tip Derg, Firat Med. J. 20 (2015) $225-228$.

[45] B. Yuksel, N. Gokay, Tip I Poliglanduler Sendrom Olgu Sunumu, Türkiye Klinikleri Pediatri Dergisi 9 (2000) 106-108.

[46] M. Halonen, H. Kangas, T. Rüppell, T. Ilmarinen, J. Ollila, M. Kolmer, M. Vihinen, J. Palvimo, J. Saarela, I. Ulmanen, P. Eskelin, APECED-causing mutations in AIRE reveal the functional domains of the protein, Hum. Mutat. 23 (2004) 245-257, http://dx.doi.org/10.1002/humu.20003.

[47] J. Perheentupa, APS-I/APECED: the clinical disease and therapy, Endocrinol. Metab. Clin. N. Am. 31 (2002) 295-320.

[48] M. Heino, P. Peterson, J. Kudoh, N. Shimizu, S.E. Antonarakis, H.S. Scott, K. Krohn, APECED mutations in the autoimmune regulator (AIRE) gene, Hum. Mutat. 18 (2001) 205-211, http://dx.doi.org/10.1002/humu.1176.

[49] A. Fierabracci, Type 1 diabetes in autoimmune Polyendocrinopathy-candidiasisectodermal dystrophy syndrome (APECED): a "rare" manifestation in a "rare" disease, Int. J. Mol. Sci. 17 (2016), http://dx.doi.org/10.3390/ijms17071106.

[50] L. Merenmies, A. Tarkkanen, Chronic bilateral keratitis in autoimmune polyendocrinopathy-candidiadis-ectodermal dystrophy (APECED). A long-term followup and visual prognosis, Acta Ophthalmol. Scand. 78 (2000) 532-535.

[51] E.H. Kemp, M. Habibullah, N. Kluger, A. Ranki, H.K. Sandhu, K.J. Krohn, A.P. Weetman, Prevalence and clinical associations of calcium-sensing receptor and NALP5 autoantibodies in Finnish APECED patients, J. Clin. Endocrinol. Metab. 99 (2014) 1064-1071, http://dx.doi.org/10.1210/jc.2013-3723 Epub 2013 Jan 1.

[52] N. Kluger, M. Jokinen, K. Krohn, A. Ranki, What is the burden of living with autoimmune polyendocrinopathy candidiasis ectodermal dystrophy (APECED) in 2012? A health-related quality-of-life assessment in Finnish patients, Clin. Endocrinol. 79 (2013) 134-141. 